\title{
Carcass Composition of West African Dwarf (WAD) Goats Fed Cassava Peel-Based Diets
}

\author{
Christopher Adams Eneji ${ }^{1}$, Godfrey Adokiye Kalio ${ }^{2}$ \& Oluwatosin Kennedy-Oko ${ }^{1}$ \\ ${ }^{1}$ Department of Animal Science, University of Calabar, Nigeria \\ ${ }^{2}$ Department of Agricultural Science, River State University of Education, Nigeria \\ Correspondence: Christopher Adams Eneji, Department of Animal Science, University of Calabar, P.M.B. 1115, \\ Calabar, Nigeria. Tel: 234-803-656-7727.E-mail: eneji2005@yahoo.com
}

Received: March 3, 2014 Accepted: October 10, 2014 Online Published: December 29, 2014

doi:10.5539/jfr.v4n1p168 URL: http://dx.doi.org/10.5539/jfr.v4n1p168

\begin{abstract}
To investigate the effects of cassava peel-based diets on the meat composition of WAD goats, 24 five month-old goats were used for the experiment. Results show that the Dry Matter (DM), Crude Protein (CP) and Nitrogen Free Extract (NFE) content of the meat were not significantly $(\mathrm{P}>0.05)$ different. The DM, CP and NFE content ranged from $29.96-30.00 \%, 89.77-90.43 \%$ and 2.00-4.03\% respectively. The mineral composition revealed no significant $(\mathrm{P}>0.05)$ differences in Iron $(\mathrm{Fe})$, Calcium $(\mathrm{Ca})$, Sodium $(\mathrm{Na})$, Zinc $(\mathrm{Zn})$, Magnesium $(\mathrm{Mg})$, Potassium $(\mathrm{K})$, Phosphorus $(\mathrm{P})$ and Copper $(\mathrm{Cu})$ content. The Fe, $\mathrm{Ca}, \mathrm{Na}, \mathrm{Zn}, \mathrm{Mg}, \mathrm{K}, \mathrm{P}$ and $\mathrm{Cu}$ content ranged from 1.95-2.20mg, $23.65-25.29 \mathrm{mg}$, 72.86-77.05mg, 4.00-4.32mg, 55.65-57.83mg and 1.62-1.73mg respectively. From the results, it appears that cassava peels supplemented with sweet potato foliage could improve the meat composition of WAD goats.
\end{abstract}

Keywords: chevon, carcass composition, alternative feed sources, cassava peels

\section{Introduction}

Carcass quality is defined as the proportion of muscle to bone and fat in the carcass (Obioha, 1992). According to Agiang et al. (2009), meat quality depends largely on the nutritive values, proximate and mineral compositions of the feeding materials. Ihekoronye and Ngoddy (1985) also noted that the age of the animal could influence meat quality as impact of marbling increases as the animal matures. Several studies indicated that carcass quality can be improved by the reduction of fat contents in the meat through dietary manipulation involving changes in the physical form of feed, energy to protein ratio (Ojewola \& Longe, 1999) and inclusion of high fibre levels (Tewe \& Egbunike, 1992). One of the feed resources exploited for its high fibre contents is Cassava peel (CSP).

Cassava has played a minor role as an ingredient in livestock feed in sub-Saharan Africa as cassava was often more expensive than imported maize (Tewe, 2004). The recent rising cost of maize on the continent due to weather induced fluctuations, huge foreign debts and currency devaluation has forced a number of countries in Africa to search for alternatives to maize particularly for its livestock sub-sector (Nweke et al., 2002).

A total production of 87 million tonnes of cassava produced annually in Africa, only 6 percent is used in livestock production mainly in traditional systems. By contrast, in Latin America, 32.4 percent of its cassava is used for livestock feeding while in Asia, over 40 percent of its products is exported in the form of chips and pellets for the European Union livestock industry with another 2.9 percent used for domestic livestock production (International Fund for Agricultural Development - IFAD and Food and Agriculture Organization of the United Nations - FAO 2000).

The share of African cassava production used as livestock feed is probably underestimated because cassava wastes such as peels, and leaves are fed to goats, sheep and pigs on small-scale farms in traditional systems, in fresh or cut-and-dried forms (Nweke et al., 2002). In West Africa, waste from cassava production is between 5 52 percent thus, is a potential feed resource for the regions (Tewe, 2004). Goat and sheep rearing are highly complementary because cassava processing is carried out around homes, and goats, sheep and chicken are fed by-products of cassava processing. As a complementary energy source, CSP can undergo stratification within the rumen, so it can be regurgitated with forages and chewed during rumination. 
Effects of feeding cassava peels (CSP) on animal performances have been documented (Smith, 1992; Tewe et al., 2002). However, there is no report concerning the effects of dietary inclusion of CSP on meat composition in WAD goats. According to Al-Bachir and Zeinou (2014) goat meat compared to other traditional red meat is recognized as an important protein source and is preferred due to its lower total fat and higher unsaturated fatty acid content.

Therefore, this study evaluated the effects of treated and foliage supplemented-cassava peel diets on the meat composition of West African Dwarf goats. To improve the per capita animal protein intake and profitability of goat farming, the best CSP-forage feeding regime was evaluated.

\section{Materials and Methods}

\subsection{Experimental Diets and Management}

To assess the effects of cassava peels based- diets on the meat composition of West African dwarf (WAD) goats, four dietary treatments; cassava peels treated with Urea (CSP + U), cassava peels treated with broiler litter (CSP $+\mathrm{BL}$ ), cassava peels supplemented with cassava foliage (CSP + CSF) and cassava peels supplemented with sweet potato foliage (CSP + SPF) were fed to 5 months -old bucks for 90 days. The chemical compositions of the four diets were analyzed using standard methods (AOAC, 2000).

A total of 24 bucks were studied with each treatment having 3 replicates of 3 bucks. Each replicate were housed in individual pens. Each supplement was included at 3\% Bw (i.e. $162.24 \mathrm{~g}$ of cassava plus $40.56 \mathrm{~g}$ supplement per treatment). The average daily feed intake for each treatment was: $104.27 \mathrm{~g}(\mathrm{CSP}+\mathrm{U}), 107.82 \mathrm{~g}(\mathrm{CSP}+\mathrm{BI})$, $276.07 \mathrm{~g}(\mathrm{CSP}+\mathrm{CSF})$ and 265.45 (CSP + SPF). Prior to the commencement of the experiment, one week acclimatization period was permitted. The animals had free access to water during the experiments. The total amounts of mixed rations offered and refused were recorded daily and the daily voluntary intake (DVI) was recorded.

\subsection{Meat Sampling and Analyses}

At the expiration of the 90 days growth trial, one animal was selected per replicate for proximate and chemical analysis. Prior to slaughter these animals were fasted for 24 hours and was provided with portable drinking water. The animals were cleaned by the use of over-head water sprays which helps to cool the animal and facilitates the removal of blood as they move one after the other into the slaughter room. The animals were killed as quickly as possible to avoid stress and depletion of glycogen reserves by inserting a sharp knife in front of the breast or brisket and severed the carotid arteries and jugular vein. The animals with their hind legs tied were flayed hanging upside down by archile tendon for bleeding for 30 minutes. This is followed by skinning and evisceration-removal of viscera. The carcasses were cut into wholesale cuts. The thigh and forearm muscles were deboned and washed. A total of $18.80 \mathrm{~g}$ meat sample was collected from each animal and refrigerated for 24 hours at a temperature of between $6{ }^{\circ} \mathrm{C}$ to $10{ }^{\circ} \mathrm{C}$ for glycolysis to take place converting the muscles to meat. These samples were chopped into smaller pieces using a kitchen knife, thereafter oven dried at $45{ }^{\circ} \mathrm{C}$ to a constant weight. The dried meat samples were milled using Thomas Wiley laboratory mill model 4 (WM4 mill) with $1 \mathrm{~mm}$ sieve. The homogenous powder was stored in well-labeled sample bottles for chemical analysis.

\subsection{Proximate Analysis}

Dry Matter (DM), crude protein (CP), ether extract (EE), ash and nitrogen free extract (NFE) from muscle samples of the four treatments were determined using standard methods (AOAC, 2007).

\subsection{Mineral Determination}

Ten grams of each meat sample was weighed into analytical round bottomed flask. Minerals in the ash were brought into solution by wet digestion using concentrated nitric acid (63\%), concentrated perchloric acid (60\%) and concentrated sulphuric acid (98\%) mixture in the ratio of 4:1:1 (Harris, 1970). Potassium and Sodium were determined with flame photometer (Collins and Polkin Horne model) Baush-Lamb spectronic 20 was used for phosphorous, (Allen, 1974) method. The other minerals were determined using Perkin-Elmer Atomic Absorption Spectrophotometer (AAS) model 290B (AOAC, 2000). All determinations were in triplicates and mean values were evaluated.

\subsection{Statistical Analysis}

All data were subjected to one-way analysis of variance (ANOVA) and treatment means were separated using the Duncan's new multiple range test (Steel et al., 1996). Means and Standards deviations were calculated following established statistical procedures (J. C. Miller \& J. N. Miller, 1986). A probability P $<0.05$ was used to test the statistical significance. 


\section{Results}

Results obtained from the study are summarized in Tables 1-3.

\subsection{Proximate Composition}

Table 1 shows the proximate composition of experimental diets. The acid detergent fibre (ADF) and the neutral detergent fibre $(\mathrm{NDF})$ were significantly $(\mathrm{P}<0.05)$ different. The calculated metabolizable energy $(\mathrm{ME})$ of the feedstuffs were significantly $(\mathrm{P}<0.05)$ different.

Table 1. Proximate composition of experimental diets (as fed basis)

\begin{tabular}{cccccccc}
\hline & \multicolumn{7}{c}{ Feed samples } \\
\cline { 2 - 8 } Nutrients (\%) & $\begin{array}{c}\mathbf{T}_{\mathbf{1}} \\
(\mathbf{C S P}+\mathbf{U})\end{array}$ & $\begin{array}{c}\mathbf{T}_{\mathbf{2}} \\
(\mathbf{C S P}+\mathbf{B L})\end{array}$ & $\begin{array}{c}\mathbf{T}_{\mathbf{3}} \\
(\mathbf{C S P}+\mathbf{C S F})\end{array}$ & $\begin{array}{c}\mathbf{T}_{\mathbf{4}} \\
(\mathbf{C S P}+\mathbf{S P F})\end{array}$ & Mean & \pm SEM & \pm STD \\
\hline Dry matter (DM) & 89.07 & 89.77 & 86.24 & 88.65 & 88.43 & 2.90 & 1.33 \\
Crude protein (CP) & $30.05^{\mathrm{a}}$ & $25.00^{\mathrm{b}}$ & $16.02^{\mathrm{d}}$ & $18.04^{\mathrm{c}}$ & 22.28 & 1.95 & 5.59 \\
Ether extract (EE) & $6.04^{\mathrm{c}}$ & $10.05^{\mathrm{b}}$ & $14.00^{\mathrm{a}}$ & $13.00^{\mathrm{a}}$ & 10.77 & 1.17 & 3.66 \\
Crude fibre (CF) & 15.05 & 17.00 & 19.55 & 20.06 & 17.92 & 1.38 & 2.02 \\
Ash & 16.00 & 16.05 & 20.04 & 18.01 & 17.53 & 1.49 & 1.66 \\
Nitrogen free extract (NFE) & $32.86^{\mathrm{a}}$ & $31.90^{\mathrm{a}}$ & $30.39^{\mathrm{b}}$ & $30.89^{\mathrm{b}}$ & 31.51 & 1.06 & 0.95 \\
Acid detergent fibre (ADF) & $16.00^{\mathrm{d}}$ & $26.00^{\mathrm{c}}$ & $32.00^{\mathrm{b}}$ & $34.00^{\mathrm{a}}$ & 27.00 & 1.96 & 7.00 \\
Neutral detergent fibre (NDF) & $30.06^{\mathrm{d}}$ & $40.00^{\mathrm{c}}$ & $50.05^{\mathrm{b}}$ & $56.00^{\mathrm{a}}$ & 44.03 & 3.05 & 9.88 \\
*Metabolizable energy & $12.00^{\mathrm{a}}$ & $10.55^{\mathrm{b}}$ & $7.94^{\mathrm{c}}$ & $7.95^{\mathrm{c}}$ & 9.61 & 0.58 & 1.74 \\
(MJ/kg DM) & & & & & & & \\
\hline
\end{tabular}

Not significantly different $(P>0.05)$. ${ }^{\text {a,b,c,d }}$ Means bearing different superscripts along the same row are significantly different $(P<0.05)$. ${ }^{*} \mathrm{EE}(\mathrm{MJ} / \mathrm{kgDM})$.

$\mathrm{CSP}+\mathrm{U}-$ Cassava peels treated with urea. $\mathrm{CSP}+\mathrm{BL}-\mathrm{Cassava}$ peels treated with broiler litter.

$\mathrm{CSP}+\mathrm{CSF}-\mathrm{Cassava}$ peels supplemented with cassava forage.

$\mathrm{CSP}+\mathrm{SPF}-$ Cassava peels supplemented with sweet potato forage.

Table 2 Shows the Proximate Composition of meat from WAD goats fed cassava peel diets. The DM, CP and NFE content of meats between dietary treatments.

Table 2. Proximate composition of meat from WAD goats fed cassava peel diets

\begin{tabular}{|c|c|c|c|c|c|c|c|}
\hline \multirow[b]{2}{*}{ Nutrients $(\%)$} & \multicolumn{6}{|c|}{ Meat samples } & \multirow[b]{2}{*}{$\pm \mathbf{S T D}$} \\
\hline & $\begin{array}{c}\mathrm{T}_{1} \\
(\mathrm{CSP}+\mathrm{U})\end{array}$ & $\begin{array}{c}\mathbf{T}_{2} \\
(\mathrm{CSP}+\mathrm{BL})\end{array}$ & $\begin{array}{c}\mathbf{T}_{3} \\
(\mathrm{CSP}+\mathrm{CSF})\end{array}$ & $\begin{array}{c}\mathbf{T}_{4} \\
(\mathrm{CSP}+\mathrm{SPF})\end{array}$ & Mean & \pm SEM & \\
\hline Dry matter (DM) & 30.00 & 29.99 & 29.96 & 29.97 & 29.98 & 2.20 & 0.016 \\
\hline Crude protein $(\mathrm{CP})$ & 89.77 & 90.38 & 89.87 & 90.43 & 90.11 & 2.38 & 0.295 \\
\hline Ether extract (EE) & $6.67^{\mathrm{a}}$ & $6.04^{\mathrm{b}}$ & $5.25^{\mathrm{c}}$ & $4.25^{\mathrm{d}}$ & 5.55 & 0.37 & 0.905 \\
\hline Ash & $2.00^{\mathrm{c}}$ & $2.00^{\mathrm{c}}$ & $3.59^{\mathrm{b}}$ & $4.03^{\mathrm{a}}$ & 2.91 & 0.23 & 0.918 \\
\hline Nitrogen free extract (NFE) & 1.56 & 1.58 & 1.29 & 1.29 & 1.43 & 0.01 & 0.140 \\
\hline
\end{tabular}

$\overline{\mathrm{a}, \mathrm{b}, \mathrm{c}, \mathrm{d}}$ Means with different superscripts are significantly $(P<0.05)$ different across row.

$\mathrm{CSP}+\mathrm{U}-$ Cassava peels treated with urea. $\mathrm{CSP}+\mathrm{BL}-$ Cassava peels treated with broiler litter

$\mathrm{CSP}+\mathrm{CSF}-\mathrm{Cassava}$ peels supplemented with cassava forage.

$\mathrm{CSP}+\mathrm{SPF}-$ Cassava peels supplemented with sweet potato forage 


\subsection{Minerals}

Table 3 shows the Mineral Composition of meat from WAD goats fed cassava peel diets. The results of mineral composition revealed no significant ( $\mathrm{p}>0.05$ ) differences. Potassium had the highest across all the meat samples.

Table 3. Mineral Composition of meat from WAD goats fed cassava peel diets

\begin{tabular}{|c|c|c|c|c|c|c|c|}
\hline \multirow[b]{2}{*}{ Minerals (mg/100g) } & \multicolumn{6}{|c|}{ Meat samples } & \multirow[b]{2}{*}{ \pm STD } \\
\hline & $\begin{array}{c}\mathrm{T}_{1} \\
(\mathrm{CSP}+\mathrm{U})\end{array}$ & $\begin{array}{c}\mathrm{T}_{2} \\
(\mathrm{CSP}+\mathrm{BL})\end{array}$ & $\begin{array}{c}\mathrm{T}_{3} \\
(\mathrm{CSP}+\mathrm{CSF})\end{array}$ & $\begin{array}{c}\mathrm{T}_{4} \\
(\mathrm{CSP}+\mathrm{SPF})\end{array}$ & Mean & \pm SEM & \\
\hline Iron $(\mathrm{Fe})$ & 2.00 & 1.95 & 2.05 & 2.20 & 2.05 & 0.36 & 0.093 \\
\hline Calcium $(\mathrm{Ca})$ & 24.50 & 23.65 & 24.82 & 25.29 & 24.57 & 1.12 & 0.598 \\
\hline Sodium $(\mathrm{Na})$ & 73.90 & 72.86 & 75.90 & 77.05 & 74.93 & 2.68 & 1.642 \\
\hline Zinc (Zn) & 4.00 & 4.30 & 4.32 & 4.29 & 4.23 & 0.32 & 0.132 \\
\hline Magnesium (Mg) & 24.05 & 23.25 & 24.01 & 23.70 & 23.75 & 2.47 & 0.320 \\
\hline Potassium (K) & 306.75 & 308.00 & 308.32 & 307.83 & 307.73 & 3.51 & 0.589 \\
\hline Phosphorus (P) & 56.50 & 55.65 & 56.78 & 57.83 & 56.69 & 1.86 & 0.778 \\
\hline Copper $(\mathrm{Cu})$ & 1.62 & 1.65 & 1.68 & 1.73 & 1.67 & 0.04 & 0.041 \\
\hline
\end{tabular}

No significant $(P>0.05)$ differences across row.

$\mathrm{CSP}+\mathrm{U}-$ Cassava peels treated with urea. $\mathrm{CSP}+\mathrm{BL}-$ Cassava peels treated with broiler litter.

CSP+CSF-Cassava peels supplemented with cassava forage.

$\mathrm{CSP}+\mathrm{SPF}-$ Cassava peels supplemented with sweet potato forage.

\section{Discussion}

\subsection{Proximate Composition}

Results on Table 1 shows that $\mathrm{CP}$ content varied significantly $(\mathrm{P}<0.05)$ between feed samples Urea treated cassava peel had the highest value, while the least was recorded in the cassava peel and foliage group. Ether extract was also influenced by dietary samples. Urea treated cassava peel had the least EE value. Comparable NFE was recorded in Urea and broiler litter groups as well as cassava and sweet potato groups. ADF and NDF content were lower in Urea treated group value compared to the foliage groups. Metabolized energy was highest in Urea group value followed by broiler litter, cassava and sweet potato foliages values. The (ME) values of the feedstuffs are within the recommended levels $(6-13 \mathrm{MJ} / \mathrm{KgDM})$ for maintenance and production for goats (Steele, 2006).

Results on proximate analysis (Table 2$)$ showed that EE values decreased significantly $(\mathrm{P}<0.05)$ in meat from cassava and sweet potato foliages compared to meat fed Urea treated cassava peels. On the other hand, ash content was highest $(\mathrm{P}<0.05)$ in cassava and sweet potato leaves than in Urea and broiler litter groups. However, differences were observed in the values for DM, CP, and NFE contents of meat between dietary treatments. The effect of higher $\mathrm{CP}$ content observed in the diet of bucks supplemented with Urea was not reflected in the meat composition. This could suggest that Urea could have been undergoing further decomposition or utilized by the microbes in the goat's rumen rather than for muscle growth. Supplementation with sweet potato foliages however increased $(\mathrm{P}<0.05) \mathrm{CP}$ and ash content of the meat while decreasing the amount of fat in the meat, thus improving the nutritive value of the meat compared to those supplemented with cassava foliage and broiler litter. The values for CP content of the meat samples were similar to those reported by Agiang et al. (2009) for rabbits but higher than those reported by Eniolorunda et al. (2011) for Yankasa rams fed graded levels of biscuit wastes. The NFE and ash contents of meat samples were higher than those reported by Agiang et al. (2009) for rabbits. The EE content of meat were less than those by Eniolorunda et al. (2011) for Yankasa rams but greater than those reported by Agiang et al. (2009) for rabbits.

\subsection{Mineral Elements}

The results of mineral composition on Table 3 revealed no significant $(\mathrm{P}<0.05)$ differences. Value for potassium was the highest across all meat samples followed by $\mathrm{Na}, \mathrm{P}, \mathrm{Ca}, \mathrm{Mg}, \mathrm{Fe}$ with the least value in copper 
content. The values obtained were slightly higher than the values reported by Johnson (1987) for wood and wood crossbred goats of Florida. According to Agiang et al. (2009) differences observed in the crude protein content of meat samples is a function of the nutrient composition of the diet. Similarly, Ahmed et al. (2010) noted that the chemical composition of meat could be improved by factors such as animal species, breed, anatomical location of muscle and nutrition. The variations observed in the proximate and mineral composition of the meat from WAD goats may be attributed to the degree of interactions between the diet and the genetic constitutions of the goats.

\section{Conclusion}

From the study, results indicated that varying materials used for cassava peel supplementation may not have adverse effects on the nutritional qualities of the meat of WAD goats. Variations in the chemical composition of the feeding materials (cassava peels treated with $\mathrm{N}$ - sources or forage supplementation) had no significant impact on the nutritional qualities of meat from WAD goats. Nevertheless, cassava peel supplemented with sweet potato forage improved the nutritive qualities of meat of WAD goats.

Thus, this study concludes that sweet potato foliage should be supplemented into cassava peel-based diet, for improved meat quality for WAD goats.

\section{References}

Aduku A. O., \& Olukosi J. O. (2000). Animal Products Processing and Handling in the Tropics (2nd ed) (pp. 9-13). Living Books Series, G.U. Publications, Abuja, Nigeria.

Agiang, E. A., Eneji, C. A., Iso, I. E., \& Isika, M. A. (2009). Effects of mixed-feeding on physiolgical development and nutritional qualities of rabbit reat. Journal of Agiculture, Biotechnology and Ecology, 2, 69-77.

Ahmed, A. G. A., Muzani, A., \& Samir, H. A. I. (2010). Quality and sensory evaluation of meat from Nilotic male kids fed on two different diets. Journal of Animal and Veterinary Advances, 9(15), 2008-2012. http://dx.doi.org/10.3923/javaa.2010.2008.2012

Al-Bachir, M., \& Zeinou, R. (2014). Effect of Gamma irradiation on the microbial load chemical and sensory properties of Goat meat. Acta Alimentaria, 43(2), 264-272. http://dx.doi.org/10.1556/AAlim.43.2014.2.10

Allen, S. G. (1974). Chemical Analysis of Ecological Materials. 140. Oxford, U.K: Blackwell Scientific Publications.

AOAC. (2007). Official Methods of Analysis (18th ed.). Washington D. C: Association of Official and Analytical Chemists.

Eniolorunda, O. O., Apata, E. S., Badejo, B. B., \& Okubanjo, A. O. (2011). Evaluation of the meat quality of Yankasa rams fed graded levels of biscuit waste. Nigerian Journal of Animal Production, 38(1), 153-159.

Harris, E. (1970). Nutrition Research for Domestic and Wild Animals, SI. 150. Utah, U.S.A: Utah Publishing Co.

IFAD \& FAO. (2000). The World Cassava Economy: Facts and outlook. International Fund for Agricultural Development and Food and Agriculture Organization of the United Nations, Rome.

Ihekoronya, A. I., \& Ngoddy, P. O. (1985). Integrated Food Science and Technology for the Tropics. pp. 330-332. MCM, International Coll.

Johnson, E. (1987). USDA Human Nutrition Hand Book. No. 5. 8-5.

Miller, J. C., \& Miller, J. N. (1986). Statistics for Analytical Chemistry (2nd ed.). Chichester, UK: Ellis-Horwood.

Obioha, F. C. (1992). A Guide to Poultry Production in the Tropics (1st ed.). (pp. 11-43). Lagos, Nigeria: Arena Publisher.

Ojewola, G. S., \& Longe, O. G. (1999). Protein and energy in broiler starter diets: Effect on Growth performance and nutrient utilization. Nigerian Journal of Animal Production, 26, 23-28.

Omojola, A. B., \& Attah, S. (2006). Carcass and non carcass components of male West African dwarf goats slaughtered at different weights. Tropical Journal of Animals Science, 9(2), 119-126.

Omole, T. A., \& Tewe, O. O. (1991). Processing Technology for Nigerian Feedstuffs. Paper No. 183. Document Prepared for the Presidential Task Force on Alternative Feed Formulation for Nigeria. 
Smith, O. B. A. (1992). A review of ruminant responses to cassava-based diets. In S. K. Hahn, L. Reynolds \& G. N. Egbunike (Eds.), Cassava as livestock feed in Africa (pp. 39-63). Ibadan, Nigeria: University Press.

Steel, R. G. D., Torrie, J. H., \& Dickey, D. (1996). Principles and Procedures of Statistics. McGraw-Hill.

Steele, M. (2006). Goats. CTA-Macmillan Publishing Ltd. London and Basingstoke. 152.

Tewe, O. O., \& Egbunike, G. N. (1992). Utilization of cassava in non-ruminant livestock feed. In R. Hahn \& G. N. Egbunike (Eds.), Workshop for Cassava as Livestock Feed for Africa (pp. 28-38).

Tewe, O. O., Bokanga, M., Dixon, A. G. O., \& Larbi, A. (2002). Strategies for cost effective cassava plant-based feeds for livestock and fish. Commissioned paper presented at the Regional Workshop on Improving the Cassava Sub-sector, Nairobi, Kenya.

Tewe, O. O. (2004). Cassava for livestock feed in sub-Saharan Africa. In NeBambi Lutaladio (Ed.), The Global Development Cassava Strategy 75. FAO Paper, Plant Production and Protection Division Food and Agriculture Organization of the United Nations.

\section{Copyrights}

Copyright for this article is retained by the author(s), with first publication rights granted to the journal.

This is an open-access article distributed under the terms and conditions of the Creative Commons Attribution license (http://creativecommons.org/licenses/by/3.0/). 